\title{
ECOTOURISM IN RURAL DEVELOPING COMMUNITIES
}

\author{
Lisa M. Campbell \\ University of Western Ontario, Canada
}

\begin{abstract}
This paper considers the ad hoc development of ecotourism at Ostional, Costa Rica, and the potential benefits for the local community in the absence of government planning or intervention. In 1995, only four percent of Ostional households identified tourism as a source of income; however, this was substantial in comparison to that derived from other economic activities. While most Ostional residents had positive attitudes toward tourism, they had limited awareness of employment or investment opportunities. Lack of awareness, along with increased activity by outside investors, suggests that, in the absence of formalized planning or intervention, the possibilities for the community at Ostional to further benefit from tourism development will be limited. Keywords: alternative ecotourism, community participation, wildlife conservation. (C) 1999 Elsevier Science Ltd. All rights reserved.
\end{abstract}

Résumé: L'Écotourisme dans des communautés rurales en voie de développement. Cet article examine l'évolution improvisée de l'écotourisme à Ostional au Costa Rica et ses avantages potentiels pour la communauté en absence d'organisation et d'intervention gouvernementales. En 1995, seulement quatre pour cent de la population d'Ostional signalaient le tourisme comme source de revenu, ce chiffre était pourtant considérable par rapport aux revenus obtenus de toutes autres activités économiques. Bien que la plupart des habitants d'Ostional se montraient favorables aux tourisme, ils faisaient preuve d'une conscience limitée d'occasions pour l'emploi et pour les investissements économiques. Cette conscience limitée, ajouté àune activité financière intensifiée des investisseurs extérieurs, suggère que, sans planification ou intervention formelles, les bénéfices possibles du tourisme pour la communauté d'Ostional seront limités. Mots-clés: éco-tourisme alternatif, participation communautaire, la défense de l'environnement. (C) 1999 Elsevier Science Ltd. All rights reserved.

\section{INTRODUCTION}

Tourism is widely believed to be the most rapidly growing global industry, and the World Tourism Organization predicts international tourism will grow at approximately 4\% per year through the year 2010 (World Tourism Organization 1996). While difficult to measure, ecotourism is believed to be the fastest growing tourism segment (Buckley 1994; Deardon and Harron 1993; Ecotourism Society 1998; Wild 1994). Estimates by Filion, Foley and Jacquemot (1994) suggest that in 1988 there were between 157 and 236 million

Lisa Campbell (Department of Geography, University of Western Ontario, London, Ontario, Canada N6A 5C2. Email 〈lcampbe@julian.uwo.ca〉) is Assistant Professor in Geography. She is interested in strategies for reconciling the objectives of wildlife conservation with those of rural development, and in the role of local communities in implementing such strategies, particularly in developing countries. 
international ecotourists, generating economic impacts of $\$ 93$ billion to $\$ 233$ billion. In Costa Rica, a country which has increasingly tailored its industry to fit the ecotourism niche (Evans-Pritchard 1993; Schlüter 1993), foreign exchange receipts from tourism have surpassed those earned by traditional export products (coffee and bananas), to become the country's most important economic activity (ICT 1993).

There is considerable debate over what ecotourism really means, however, and estimates of value generated by Filion et al (1994) are based on a definition of the form which allows tourists to enjoy and appreciate nature. This reflects the original ecotourism definition provided by Ceballos-Lascurain (cited in Boo 1990) and popularized by Boo (1990), that focused on the site or object of tourist viewing. As ecotourism has grown in popularity, sometimes resembling traditional mass tourism, its definitions have been expanded to incorporate ideas about ecotourist responsibility, environmentally friendly destination management, profit linkages to conservation efforts, and the sustainable development of local human populations.

Ecotourism can be defined in terms of the "product" or as an operating "principle" (Cater 1994a). Buckley (1994), Ormans (1995), and Stewart and Sekartjakrarini (1994) review its definitions and conclude that preference for one over another reflects different priorities of actors and analysts. Thus, while Ormans (1995) favors a definition that focuses on encouraging better ecotourists who will help maintain a better environment, and Blangy and Nielsen (1993) focus on guidelines for operators (product-oriented definitions), proponents of local development find these types of definitions inadequate, or incomplete. While Stewart and Sekartjakrarini (1994) argue that the multifaceted nature of expanded, principle-based definitions leads to ambiguity in interpretation, a definition which includes community development is increasingly promoted (Boo 1992; Budowski cited in Kutay 1992, Cater 1994b; Ecotourism Society 1992, 1998; Kutay 1992; Norris 1992; Whelan 1991; Ziffer 1989). For the purposes of this paper, an expanded definition of tourism, which encompasses both visits to natural areas and the development of local communities, is referred to as alternative ecotourism.

Community participation as described by Murphy (1985) is central to the alternative ecotourism concept, with proponents arguing that participation in planning is necessary to ensure that benefits reach residents in destination areas (Simmons 1994). Cater (1994b) and Wild (1994) suggest that ecotourism which encourages local employment and small business development promotes higher economic multipliers, and that a community approach to decision-making helps to ensure traditional lifestyles and community values are respected. Kutay (1992) cites environmental benefits of community participation, arguing that a close working relationship between the local community and the industry will provide the means to support conservation efforts. Small scale, community led tourism has been 
suggested as particularly appropriate for developing countries (Britton and Clark 1987; Kangas, Shave and Shave 1995; Oppermann 1993).

In definitional discussions, there is often an underlying assumption that tourism to small rural communities will be planned and that planning with environmental and community development goals in mind will help ensure their achievement. This assumption of planning is problematic, as the level of choice exercised by host communities in becoming a destination is questionable with tourism in general, and particularly in developing countries (Cater 1994a). Based as it often is on visits to rural towns and villages in remote and undeveloped areas (Wild 1994), ecotourism is additionally problematic as it is perhaps unreasonable to expect that national planners interested in foreign exchange earnings will invest time and effort in insuring the goals of alternative ecotourism are met in such places. The size of the industry in general and the high rates of growth in ecotourism specifically suggest that, even when governments are interested, they will be unable to oversee development at all potential sites. They have sometimes intervened in ecotourism development on behalf of rural communities—such as Zimbabwe's Campfire Program (Chalker 1994), and Nepal's Annapurna Conservation Area (Gurung and De Coursey 1994). But such intervention often occurs where the natural resources in question are capable of attracting considerable tourism dollars, and/or where the industry is being promoted to reduce more consumptive forms of wildlife utilization (e.g., direct harvesting).

It could also be argued that a philosophy of alternative ecotourism, which relies on community participation and even control, minimizes the extent to which outside planning and intervention is desirable. Control over resources can be key to gaining community support for their conservation, and "top-down" rural tourism activities have sometimes failed to gain such support in spite of their provision of monetary benefits to local people (Balakrishnan and Ndhlovu 1992; Parry and Campbell 1992). Perhaps the crucial question is not "what the definition of alternative ecotourism is" or "how alternative ecotourism can be planned" but rather "what the chances are that visits to remote developing areas will meet the community development and participation objectives of alternative ecotourism in the absence of official planning or intervention, and how such chances can be increased."

This paper considers tourism at Ostional, Costa Rica, and attempts to evaluate the potential for the local community to benefit meaningfully from and/or control its development without the intervention of government or other planning agencies. Based on research undertaken at Ostional in 1994 and 1995, this paper discusses three key issues: current levels and the economic value of overnight tourism to Ostional; community perceptions of the growing industry and of opportunities for tourism-based employment; and the potential for tourism to reduce dependence on and/or con- 
flict with current livelihoods, namely, the legalized harvest of Lepidochelys olivacea (olive ridley) sea turtle eggs.

Ostional is an appropriate site to examine the potential for alternative ecotourism, for several reasons. First, the basis of tourism in Ostional is a wildlife resource, the olive ridley sea turtles which nest on Ostional beach. Second, tourism levels were low at the time of this study but evidently increasing. Third, government involvement in tourism development was minimal. Fourth, community organization in Ostional is considerable and formalized through the Ostional Development Association. In this respect, Ostional is exceptional for rural Costa Rican villages (March 1992) and it should be more prepared to organize around tourism than many

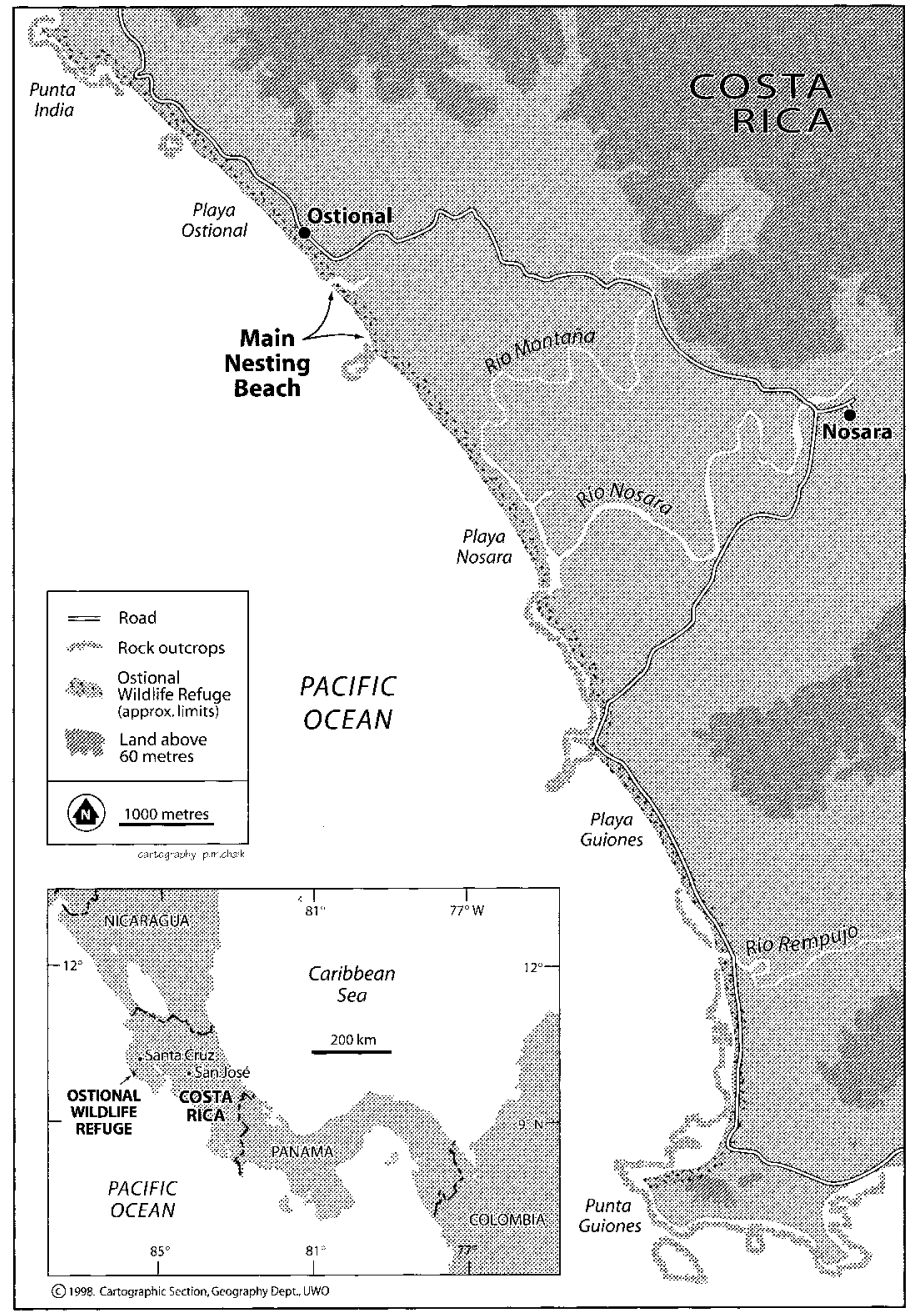

Figure 1. Ostional Wildlife Refuge, Costa Rica 
similar communities. By examining the community's attitudes towards, and preparedness for, tourism in Ostional, this research contributes to an understanding of the kinds of issues that enhance and/or limit community participation in, and control of, its development.

\section{ECOTOURISM IN OSTIONAL}

Ostional village lies within the Ostional Wildlife Refuge (the refuge), which is part of Costa Rica's protected areas system. The refuge is located on the Pacific Coast of the country, on the Nicoya Peninsula, 60 kilometers Southeast of Santa Cruz. Declared in 1983, the refuge extends 200 meters inland along 12 kilometers of coastline. It was established to protect nesting sea turtles, particularly olive ridleys, and while the entire 12 kilometers is designated as protected, the main nesting site is located in front of Ostional village, one kilometer south of the refuge's northern boundary (Figure 1). Here, an 800-meter stretch of beach acts as an olive ridley arribada beach, one of approximately nine in the world. Other arribadas occur or have occurred in Nicaragua, Panama, Surinam, Mexico, and India (NMFS/USFWS 1996). Arribada is the Spanish word for arrival and during this time olive ridleys congregate for mass nesting, which lasts from three to 10 days. This contrasts with the nesting strategies of most other species of sea turtle (and of olive ridleys at other sites), which nest individually (Hughes and Richard 1974). During arribadas, turtle behavior changes drastically and the normally skittish reptiles, frightened by lights, movement, or noise, will wrestle any obstacle, driven by their instincts to nest (Cornelius 1986). Arribadas at Ostional occur more or less monthly, with some

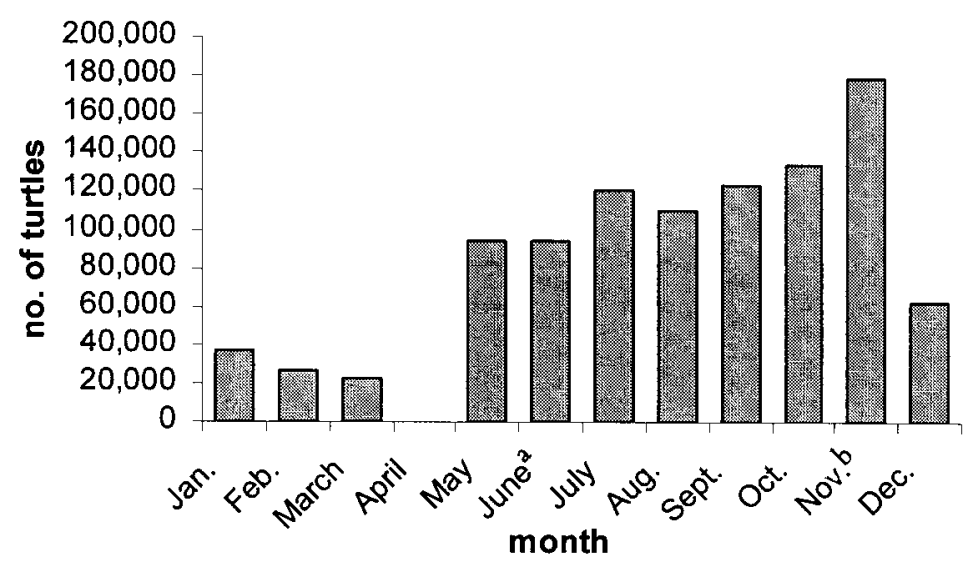

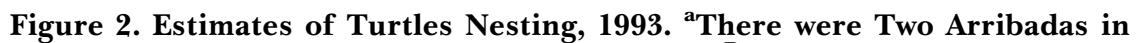
June, but Figure Number Represents Only One. ${ }^{\mathrm{B}}$ There were Two Arribadas in November, and Figure Number Represents the Total. Source: Ballestero (1994) 
months missed during the December-May dry season and with sometimes more than one arribada per month during the June to November rainy season (Ballestero 1994; personal observation 1994/ 1995). Ostional features the largest arribada beach in the Western Hemisphere and the second largest in the world (NMFS/USFWS 1996). Figure 2 shows estimated numbers of turtles nesting during 1993. Data are derived using a counting method devised by Cornelius and Robinson (1982).

Ostional village has also been home to a small human population since the 40s. At the time of this research, the population consisted of approximately 84 households composed of some 390 people. While Ostional is difficult to get to, particularly during the rainy and high nesting season for olive ridleys, it nevertheless receives both domestic and international tourists. The main attraction is the turtles, and the nature of arribada nesting makes them particularly "viewable." Not only are the turtles relatively immune to frightening, but their nesting overlaps into daylight hours, with early nesters emerging from the sea before sunset and late nesters returning after sunrise. Again, this contrasts with the nesting habits of other species, which nest almost exclusively at night and which are highly susceptible to disturbance. There is little else to recommend Ostional as a destination. The black sand beach is littered with turtle egg debris, swimming is dangerous due to a severe undertow, and the hills surrounding Ostional have been extensively deforested and converted to cattle grazing.

Institutional involvement in tourism in Ostional has been minimal. The government agency responsible for planning, the Instituto Costarricense de Turismo (Costa Rican Tourism Institute, or ICT), evaluated the area's potential in 1980, declared it non-touristic (Arqueco S.A. 1980), and has played no role in its development. In March 1995, the ICT began collecting taxes from accommodation owners (100 colones per guest, or $\$ .77$ at 1995 exchange rate). The government agency responsible for the Ostional Wildlife Refuge, the Direçion de Vida Silvestre (Wildlife Directorate, or DVS), has also played a minimal role in Ostional. The Ostional Wildlife Refuge was created at the end of a protection "boom" in Costa Rica and until 1995 there was no national funding for the Refuge. As of 1995, a DVS ranger has been stationed in Ostional to collect an entry fee from tourists visiting the Refuge. The University of Costa Rica has maintained a research laboratory in Ostional since the early 1970s (Cornelius 1981), but its participation in tourism has been directed at reducing the impacts of tourism on the turtles. Any consideration of tourism potential at Ostional, and of the community's ability to benefit from it, must keep this in mind. Tourism is developing with minimum intervention of government planning agencies and, in all likelihood, will continue to evolve in this ad hoc fashion. Attempts to date to organize around tourism in Ostional have been undertaken by the Ostional Development Association.

Current tourism services in Ostional are limited. Three sets of cabinas (cabins) exist, although one set was under construction and 
non-operational throughout the study period. Cabinas Ostional has four rooms, with a capacity for 11 guests. Cabinas Guacamaya has eight rooms, with a capacity for 12 guests. The new cabinas will have five rooms and a capacity for 10 guests. Cabinas are basic, providing beds and either private or shared bath facilities. Accommodation prices during the study period were $\$ 7.69$ per person per night at Cabinas Ostional, and $\$ 6.15$ per person per night at Guacamaya. These were raised to $\$ 8.46$ and $\$ 6.92$, respectively, in March 1995 in order to pay the ICT tax.

Other services in town include a soda (café) with a second under construction, three pulperias (small grocery stores), and a cantina (bar), all of which are owned by local families. Two restaurants have been opened by foreigners; a Hungarian-owned restaurant opened in July 1995 (the first part of a larger development), and a German-owned restaurant opened in October 1995. Guiding services are theoretically available. The Ostional Development Association has been working with the University of Costa Rica since 1992 to formalize a guiding program to serve tourists wanting to view turtles and to provide employment for local youths. However, while several free training courses had been run and badges had been issued to would-be guides, the program was nonoperational throughout the study.

The primary economic activity of the majority of Ostional households $(70 \%)$ is participation in the legalized egg-harvesting project (hereafter, the project). It capitalizes on the nesting density of olive ridley sea turtles by harvesting eggs laid in the first days of an arribada. These eggs would likely be lost in subsequent days when the "second wave" of nesting turtles dig up already laid nests, and they are believed to play a minimal role in maintaining the olive ridley population (Cornelius, Alvarado Ulloa, Castro, Malta de Valle and Robinson 1991). The history of this unique project is long and complex and beyond the scope of this paper. However, a few details are provided here, as the community's control over the project is high and stands in sharp contrast to its control over tourism development.

The egg-harvesting project was legalized through the joint efforts of the Ostional community and sea turtle biologists from the University of Costa Rica. Based on egg loss experienced at Ostional, the two groups lobbied the government to legalize a limited egg harvest. The government agreed, provided that the community formed a development association to administer the harvest (Cornelius 1985). This was done in 1985 and the Ostional Development Association's executive body, which is elected by members, manages all aspects of the project including egg collection, packaging, and national distribution. As reflected in the number of households relying on egg harvesting as their primary source of income, the benefits of the project are well distributed among community members. 


\section{Study Method}

To obtain some indication of the size and value of tourism to Ostional, a census of overnight guests at Ostional's two operational sets of cabinas was undertaken with the paid assistance of cabinas owners. Tourist nationality, length of stay, and number of companions were recorded from January 1995 to August 1995 by both cabinas owners, and from September 1995 to December 1995 by one owner. Estimates of tourism at the second cabinas for September to December 1995 have been calculated based on the average ratio of tourism levels at the two cabinas from January through August 1995. Given that tourism development in Ostional is currently minimal, local perceptions will be an important factor influencing how its development proceeds. If local people see it as beneficial, they will be more likely to support and even participate in the development. Participation will also be influenced by the extent to which they envision avenues for, and are impeded from, participating or investing in tourism, and by their impressions of it in relation to the project. To explore local perceptions of, and priorities regarding, the growing tourism segment, in-depth interviews and household questionnaires were undertaken.

Interviews were conducted with 19 Ostional residents (representing $10 \%$ of the adult population). Interviews were semi-structured, with participants guided by broad questions on topics, for example, the advantages and disadvantages of tourism, potential future development, and potential that it will conflict with the project. Interviews lasted from 20 to 75 minutes, and all were taped and transcribed. Most interviewees were selected for their role in tourism or in the project. Results of these interviews were used to help structure a household questionnaire. Due to the small size of Ostional village, a questionnaire survey of all households was attempted. In total, 76 of the 84 households were surveyed (91\%). Questionnaires were conducted orally with either the male or female household head, and the sex ratio of respondents was 2:1 (women to men). The average age of respondents was 38 and the average education level was five years of primary school. Respondents had lived in Ostional for an average of 24 years, although this varied greatly, with the oldest respondent having lived there for 55 years and the newest for less than one. The majority of respondents $(90 \%)$ were members of the project.

Questionnaire respondents were asked to identify general development possibilities and potential tourism-based employment opportunities in Ostional, both for the community at large and in which they would be interested personally, and to identify all impediments to their participation in this industry. These questions were open, with respondents encouraged to identify as many opportunities and impediments as possible. Respondents were also asked to rank how they perceived tourism to impact on the economy, the olive ridley sea turtles, and the community. Ranking choices were very good, good, neutral, bad, very bad, don't know, and other. 
Respondents were then asked to explain their rankings. In addition, they were asked about desirable future levels of tourism development. Statistical analysis of questionnaires was restricted predominantly to calculating response percentages. This was done to get an overall impression of community perceptions and there was a high level of agreement on most issues (discussed later). Systematic differentiation in the community according to sex, age, and socioeconomic indicators was not evident in analysis of results.

\section{Overnight Tourism Levels}

During interviews, local people expressed their beliefs that tourism was increasing every year, with domestic influx highest in January/February (the dry season) and international arrivals highest in the European and North American summer holiday (June, July, and August). Furthermore, interviewees suggested that international tourism remained proportionately higher than domestic during the rainy months of July through November, which correspond with peak olive ridley nesting. These beliefs were confirmed in the tourism census, and Figure 3 summarizes domestic and international person nights for 1995. Total person nights for the year were 852 , which generated $\$ 6,500$. This made tourism the most important source of income for cabinas owners; for the period January to May 1995, overnight tourism revenues paid them approximately four to seven times as much as the egg-harvesting project. While the monthly ratio between domestic and international tourists varied (as noted above), international tourism levels and overall revenues were lower than expected, due to an extremely heavy rainy season which severely limited access to Ostional, particularly in October 1995. Cabinas owners claimed this was unusual.

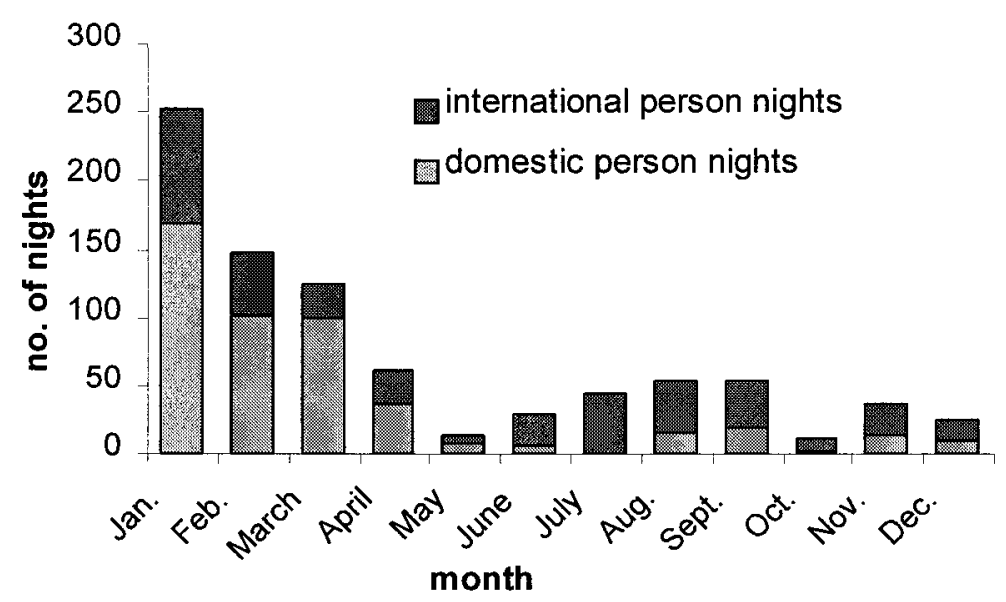

Figure 3. Domestic/International Person Nights (1995). Source: Tourism Census 
Prior to this census, tourism levels had not been measured. Now that the ICT requires cabinas owners to register and tax overnight guests, and provided this is done rigorously, there will be a basis for comparison of tourism levels. In the absence of comparative data, however, local perceptions that the industry was increasing were supported by construction of tourism facilities from year to year. Pre-1994, there was only one set of cabinas. Since 1994, the original sets' capacity has been doubled and the services and facilities described previously have been built. Increasing levels of tourism are also characteristic of the Costa Rican industry. International arrivals to Costa Rica increased an average of $16 \%$ each year from 1989 to 1993 (ICT 1993). Thus, tourism levels in Ostional are likely to continue to increase.

\section{Perceptions of Tourism}

In-depth interviews revealed a range of local attitudes and the majority of interviewees were fairly tolerant of, if not positive about, existing tourism. Overall, nine interviewees believed tourism was good, five believed it was good and bad, and five believed it was bad. These positions reflected respondents' perceptions of the economic opportunities presented by tourism (versus its environmental and the social repercussions). The most commonly cited advantage of tourism was the potential for monetary gain, and 17 of the 19 respondents identified this, including three who disapproved of tourism overall. Only two respondents stated no benefits. Twelve of them received some (often minimal) financial benefits, including all respondents in the "good" category, but one beneficiary still disapproved of tourism overall. Those who recognized financial rewards while expressing reservations about the industry felt that benefits were restricted to a small group of people (guides and business owners).

The most commonly cited disadvantage of tourism was its potential to negatively impact on the nesting olive ridley turtles. Seventeen of the 19 respondents cited the possibility of tourists disturbing turtles, and usually did so without specific prompting (i.e., when asked if tourism had any disadvantages rather than if it had any negative affects on the turtles). Three of the five individuals who were opposed to the industry based their assessments entirely on this concern. Most people who believed tourism was good recognized the potential negative impacts, but believed that guiding controlled them. As noted earlier, guiding was non-operational in Ostional during the study, and respondents in other categories were aware of this situation.

Perceptions of the social impacts of tourism were diverse. Most respondents categorizing the industry as good identified positive social aspects (i.e., meeting and having contact with other people). Conversely, respondents in both the "good and bad" and "bad" groups were concerned with the negative social impacts of tourism, and how these offset any financial benefits that exist. Specific con- 
cerns included drugs, prostitution, crime, coupling, disorder, pollution, foreign land ownership, and development (one respondent defined "good" tourists as those "who come and go away"), and the lack of government regulation for tourism development.

\section{Perceived Impacts}

Questionnaire respondents were less critical than interview respondents and classified the impacts of tourism on the economy, turtles, and community as mainly positive or neutral. Results are summarized in Figure 4.

Consistent with in-depth interview results, Figure 4 reflects the widely held belief that tourism was beneficial to Ostional's economy. Rankings of neutral, good, and very good accounted for 78\% of questionnaire responses. Fewer could justify their rankings; $24 \%$ of respondents cited money spent by tourists and the jobs generated in the community and an additional 5\% singled out guides as beneficiaries, while the remaining provided no justification for their positive rankings. Perceptions of specific economic opportunities were assessed in a separate question (discussed later).

The level of concern expressed in interviews regarding the impacts of tourism on the turtles was unmatched in questionnaire responses. Figure 4 shows that only $16 \%$ of respondents believed tourism negatively impacted on the turtles, and most (43\%) believed impacts were "neutral". Again, many respondents thought that the guiding program was in operation and cited this to justify a "neutral" ranking. Respondents who suggested tourism was good

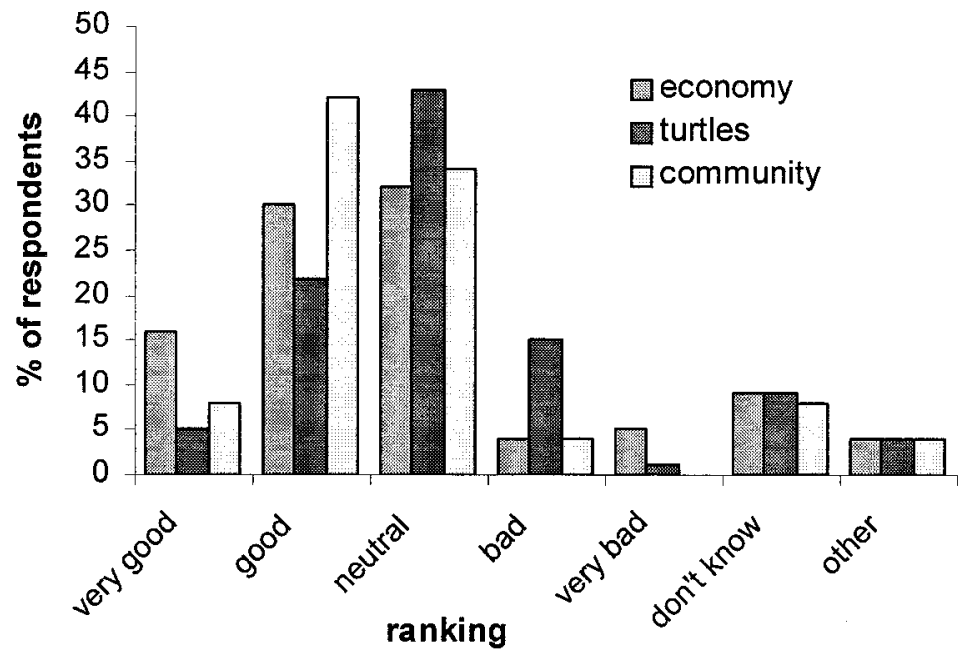

Figure 4. Perceptions of Tourism Impacts. Source: Household Questionnaire 
for the turtles believed tourists helped by protecting them on the beach and by sometimes donating money for their protection.

Questionnaire responses did not reflect the concerns over negative social impacts expressed during in-depth interviews. While 50\% of respondents suggested that tourism was good or very good for the community, only $13 \%$ linked this to a specific positive impact, including $5 \%$ who simply re-identified monetary gains. In contrast, the $8 \%$ of respondents who suggested tourism was bad for the community pointed to specific negative impacts.

In spite of the general perception that economic benefits of tourism existed, respondents had difficulty identifying specific opportunities for employment or investment. For tourism opportunities in general, 32\% could not identify any opportunities, 28\% identified only one, $22 \%$ identified two, and $15 \%$ identified more than two. Regarding tourism opportunities respondents would like to take advantage of, $43 \%$ identified no specific chances, $47 \%$ identified one (including the opportunity of doing "anything" in tourism), and only $9 \%$ identified more than one. The specific opportunities in tourism as identified and desired by respondents are shown in Figure 5. This also shows that, for all tourism opportunities, more people identified them than desired them. For example, 9\% of respondents said they would work as a guide compared to $45 \%$ who identified guiding as an opportunity. Furthermore, while $37 \%$ said they would work in "anything" related to industry, an equal number said there was no tourism job they were willing to do.

Asked to identify any and all impediments to their taking advantage of tourism opportunities, most respondents (64\%) identified only one impediment, and Figure 6 shows the most commonly perceived impediments were family responsibilities, lack of time, and

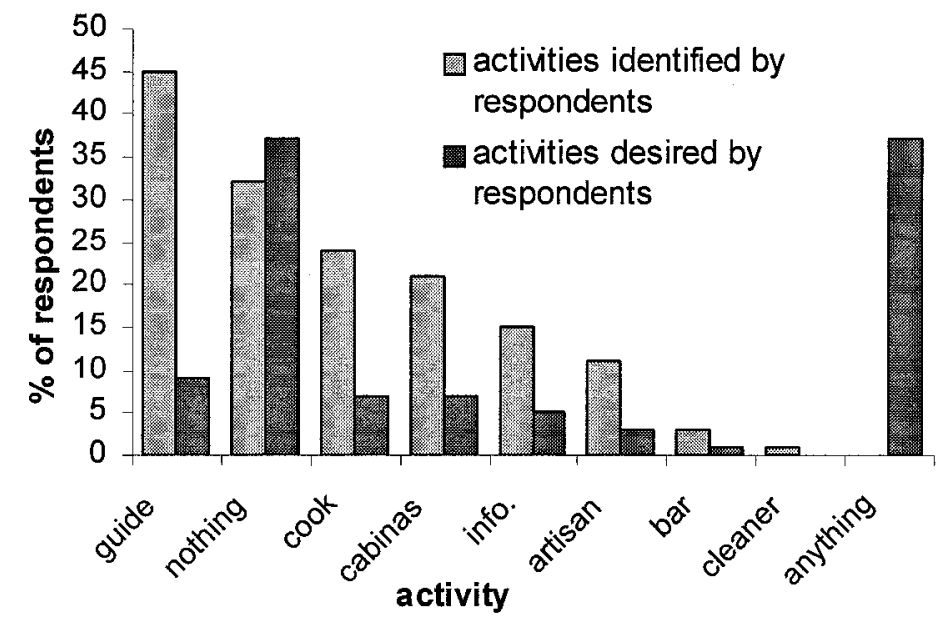

Figure 5. Identified and Desired Opportunities in Tourism. Source: Household Questionnaire 


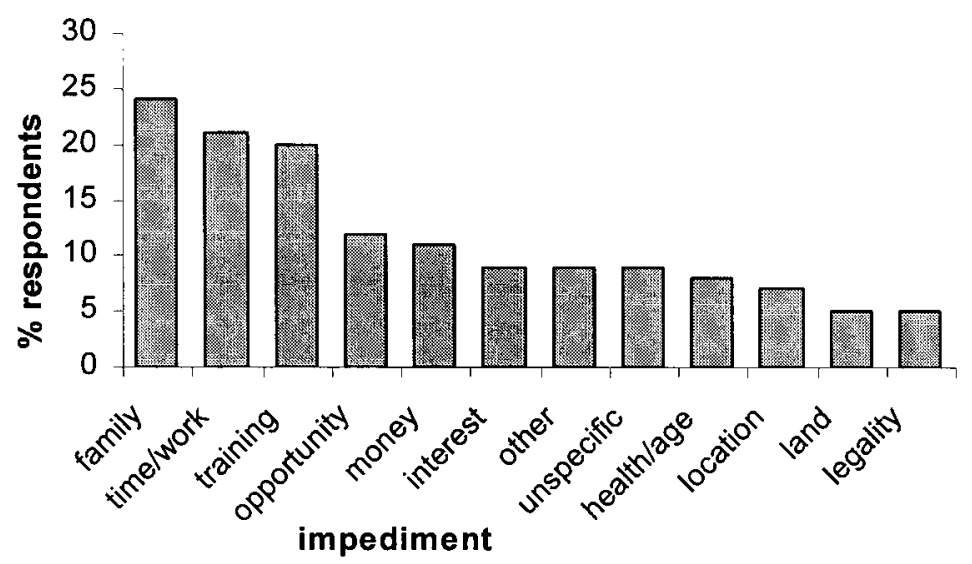

Figure 6. Identified Impediments to Working in Tourism. Source: Household Questionnaire

lack of training. Only $11 \%$ and $5 \%$ of respondents identified monetary and legal impediments, respectively, two important restrictions given the often singular and fluctuating cash income base, and the legal restrictions on land use within a national wildlife refuge (Wildlife Conservation Law 7317, 1992). Land ownership was also mildly problematic, as $38 \%$ of households lacked formal entitlement documents at the time of this research. However, only $5 \%$ identified land ownership or availability as an impediment.

\section{Desirable Future and Discussion}

Regardless of expressed reservations regarding the impacts of tourism on turtles, and in spite of the fact that few households (4\%) benefited significantly from tourism, a clear majority (72\%) of questionnaire respondents supported an increase in levels of tourism. Only $9 \%$ of these stipulated that growth should occur only with proper planning and controls. While 20\% of respondents justified their support for increased tourism in terms of monetary benefits, most $(30 \%)$ were unable to justify their position. This unexplained support for increased tourism reflects the community's desire for additional economic activity. Interview and questionnaire respondents emphasized the lack of economic opportunities in general, and all but $4 \%$ of questionnaire respondents were able to identify development they would like to see in Ostional when asked. Responses to this question contrast with the previous high level of support for increased tourism; only 12\% of respondents independently identified tourism as a type of development they would like to see, as opposed to $72 \%$ who said that tourism should increase when specifically asked about its future levels. This discrepancy is partly explained by the percentage of people who said they would like to see any kind of development in Ostional (20\% of question- 
naire respondents). While they did not necessarily think of tourism, they would be happy to see it evolve.

Current and Potential Value of Tourism. Local provision of tourism services is key to the alternative ecotourism concept. Results from this research suggest that the potential for Ostional households to both control the provision of, and benefit from, such services may be limited. This is true of accommodation and food, and guide services. Regarding the provision of the former, the 1995 census of overnight tourism showed its value has been high for households owning cabinas and both cabinas operators identified tourism as their most important source of income, more important than the egg-harvesting project. The scope for additional households to benefit in this manner, however, may be limited. First, existing cabinas were never fully occupied during this study. Assuming one person per room, occupancy rates for 1995 were $19 \%$. This rate falls to $12 \%$ when a more realistic double occupancy is assumed. The newly constructed cabinas will add five rooms with a capacity for 10 guests to the accommodation pool. Second, building cabinas is financially beyond the reach of most of the community, and thus far local investors have been relatively wealthy families. Regarding the provision of food services, there has been little investment by local households in this area. While there is currently one locally owned soda, its value to its owners remains second to that of the project. Foreigners are quickly filling any niche for investment in dining facilities and two foreignowned restaurants have opened since July 1995. That a small number of local individuals are profiting substantially from tourism is a finding comparable with other studies (Madrigal 1994; Taylor 1995).

Construction of accommodation and dining facilities within the refuge is guided by a supplement to Wildlife Conservation Law 7317, which includes restrictions on the size of buildings, lighting, and noise. At the time of this research, the regulations outlined in the supplement had not been enforced in Ostional, and construction was proceeding without the required approval. Enforcement is a possibility for the future; Direçion de Vida Silvestre established a presence in Ostional in 1995 and was preparing a management plan for the refuge. However, enforcement would disadvantage local investors as most locally owned property lies within the refuge, and foreign ownership of land within it is prohibited. As restrictions apply only to construction within the refuge, the property and buildings of foreign investors will not be subjected to Wildlife Conservation Law 7317 regulations.

The failure of the Ostional guiding program to reach an operational stage warrants discussion. The impacts of tourists on turtles via artificial lighting, flash photography, and general human disturbances are being studied at other beaches (Campbell 1994; Johnson, Bjorndal and Bolten 1996). In Costa Rica, guiding programs to minimize these impacts have been introduced at both Tortuguero National Park (Jacobson and Robles 1992) and 
Leatherbacks of Guanacaste National Park (Naranjo and Arauz 1994). Guiding in Ostional is problematic, however, for two key reasons. First, the nature of arribada nesting is a limitation. As turtles are easily found and relatively immune to frightening, both tourists and guides are unconvinced that guiding is necessary. Second, incentives for it may be lacking. Guiding has been used at other Costa Rican beaches to compensate local people for lost income (cash or subsistence) due to restrictions imposed on the consumptive use of sea turtles and their eggs. Ostional residents have access to sea turtle eggs, and their earnings from the project are substantial. Thus, the experiences of guiding programs at other Costa Rican turtle beaches are not directly applicable in Ostional. Economic contributions from guiding may change if a bylaw requiring that guides accompany tourists is introduced, a mechanism used at both Tortuguero and Leatherbacks of Guanacaste national parks.

The Ostional Development Association has attempted to increase the benefits of tourism to the community. In 1995, the association lobbied the federal government to purchase land surrounding the refuge, or expand its boundaries, in order to create a buffer zone against tourism development and to ensure that Wildlife Conservation Law 7317 applies to developments currently outside of this location. Its biologist brought a petition back from the 1995 International Symposium on the Biology and Conservation of Sea Turtles to demonstrate international scientific support for the proposed increase. The government's response, however, was simple: there are no funds to buy the land and the community should purchase it itself (personal communication with the biologist in 1995). In 1996, a Dutch nongovernmental organization was considering granting $\$ 250,000$ to the Ostional Development Association, to spend on training and capacity building for work in tourism and on the construction of association-owned cabinas. This organization eventually deemed the administrative capabilities of the association to be insufficient and the project was cancelled (personal commmunication with Ostional resident in 1996).

Potential for Change. Research showed that most of the surveyed residents of Ostional had neutral or positive impressions of tourism. There was awareness of potential and existing negative impacts of tourism on the turtles, the economy, and the community (especially among in-depth interviewees), but this did not impact on overall positive impressions of tourism, nor did it dampen the desire to see its levels increase. This finding supports the findings of King, Pizam and Milman (1993), that awareness of negative impacts did not reduce desire for increased tourism development at Nadi, Fiji. In effect, Ostional is somewhere between the first and second stages of Nemethy's (cited in Johnson, Snepenger and Akis 1994) residents' attitudes scale, which starts at welcome and progresses through development, resentment, confrontation, and destruction.

Whether the community progresses towards resentment (already expressed in some individuals) will depend in part on the ability of 
the community as a whole to benefit from tourism development, and thus avoid diversifying into Madrigal's (1994) realists, haters, and lovers. This process of diversification will be complicated by the possibility of conflict between tourism and the project. Both activities rely on the same resource and they are, to a certain extent, incompatible; tourists, interested in seeing the turtles, are often dismayed at witnessing the project (personal observation 1995). Given that $70 \%$ of Ostional households depend on the project as a primary source of income and only $4 \%$ identify tourism as such, any conflict arising as a result of this business could cause considerable upheaval in the community. The interests of Ostional's foreign investors will further complicate the matter. Thus, while tourism is seen as an attractive option at present and meets the desire for additional development, the community's optimistic feelings about it could change if such conflicts erupt.

\section{CONCLUSION}

The status of tourism in Ostional, and community perceptions of it, can be summarized into five points. One, government intervention in tourism is currently minimal. Interventions thus far are being undertaken for the benefit of the relevant government agencies, such as collection of taxes by the ICT and of refuge entrance fees by DVS. Two, the tourism industry is currently small, but valuable to those participating in it. There are few local beneficiaries, however, and foreign investment has begun. This is likely to continue and lead to inflated land prices, a process that had begun during this research (personal communication with Ostional resident in 1995). Three, there is local support for an increase in tourism, although this reflects a desire for any form of development rather than convictions about its benefits. Four, there is a low level of awareness among residents regarding specific opportunities in tourism, but also a willingness to work in "anything". This suggests that tourism initiatives will not originate in the community and individual entrepreneurs, both local and foreign, will drive tourism development.

This research illustrates some of the considerable obstacles impeding the community in Ostional from controlling the development of, and benefiting from, tourism development. In this specific case, the national government and its agencies have not intervened on behalf of the community and tourism development has indeed been ad hoc. A dismaying feature of the Ostional case is that it is potentially an ideal situation for alternative ecotourism; tourism development is currently minimal and a well organized community organization that is aware of the necessity to try and control development exists. So far, efforts of the Ostional Development Association to organize around tourism, and to seek assistance to do so, have been fruitless. If a well organized community with a history of administering a case as complicated as the egg-harvesting project cannot maintain control over tourism development, the prospects 
for other rural communities to do so are unpromising. What is at stake, in this case, is not just the opportunity to implement truly alternative ecotourism, but the future sustainability of the project. While tourism has been suggested by both the Ostional Development Association and the University of Costa Rica as a means of reducing dependence on the egg-harvesting project, it is just as likely that this project and tourism will conflict. The implications of such conflict for the community and the nesting population of olive ridley marine turtles have received inadequate attention.

Acknowledgments - The Canadian Social Sciences and Humanities Research Council provided financial support for this research. Additional support in the field came from the Worts Traveling Fund, University of Cambridge, and from the Philip Lake Fund, Department of Geography, University of Cambridge. Thanks are extended to the Ostional Development Association, the Marine Turtle Program at the University of Costa Rica, and members of the community at Ostional for their support and interest in this research. Thanks also to J. Ballestero, J.C. Castro, A. Chaves, E. Molinas, C. Niven, C. Schwarten, W.M. Adams, and J.E. Campbell.

\section{REFERENCES}

Arqueco S.A

1980 Plan Regulador: Playa Rayo-Punta Rayo, Canton de Santa Cruz. Unpublished Report to Costa Rican Tourism Institute, San José, Costa Rica.

Balakrishnan, M., and D. E. Ndhlovu

1992 Wildlife Utilization and Local People: A Case-Study in Upper Lupande Game Management Area, Zambia. Environmental Conservation 19:135-143.

Ballestero, J.

1994 Plan de Manejo para los Huevos de la Tortuga Marina Lora (Lepidochelys olivacea) en el Refugio Nacional de Vida Silvestre de Ostional, Santa Cruz, Guanacaste, Costa Rica. Unpublished Management Plan. Ostional, Costa Rica, Ostional Development Association.

Blangy, S., and T. Nielsen

1993 Ecotourism and Minimum Impact Policy. Annals of Tourism Research 20:357-360.

Boo, E.

1990 Ecotourism: The Potentials and Pitfalls, Vols 1 and 2. Baltimore: WWF.

1992 Turismo y Medio Ambiente: Posibilidades y Riesgos del Desarrollo del Ecoturismo. OMT (October 9):2-4.

Britton, S. and W. C. Clark, eds.

1987 Ambiguous Alternative: Tourism in Small Developing Countries. Suva, Fiji: University of the South Pacific.

Buckley, R.

1994 A Framework for Ecotourism. Annals of Tourism Research 21:629-642.

Campbell, C.L.

1994 The Effects of Flash Photography on Nesting Behavior of Green Turtles (Chelonia mydas) at Tortuguero, Costa Rica. In Proceedings of the 14th Annual Symposium on Sea Turtle Biology and Conservation, K.A. Bjorndal, A.B. Bolten, D.A. Johnson, P.J. Eliazar, compilers, pp. 23-24. NOAA Technical Memorandum NMFS-SEFSC-351.

Cater, E.

1994a Introduction. In Ecotourism: A Sustainable Option? E. Cater and G. Lowman, eds., pp. 3-17. Chichester: Wiley. 
1994b Ecotourism in the Third World: Problems and Prospects for Sustainability. In Ecotourism: A Sustainable Option? E. Cater and G. Lowman, eds., pp. 69-86. Chichester: Wiley.

Chalker, L.

1994 Ecotourism: On the Trail of Destruction or Sustainability? A Minister's View. In Ecotourism: a Sustainable Option? E. Cater and G. Lowman, eds., pp. 87-101. Chichester: Wiley.

Cornelius, S. E.

1986 The Sea Turtles of Santa Rosa National Park. Madrid: Incafo.

1985 Update on Ostional. Marine Turtle Newsletter 33:5-8.

1981 Status of Sea Turtles along the Pacific Coast of Middle America: Biology and Conservation of Sea Turtles. In Proceedings of the World Conference on Sea Turtle Conservation, Washington, November 1979, K. A. Bjorndal, ed., pp. 211-219. Washington DC: Smithsonian Institute.

Cornelius, S.E. and D.C. Robinson

1982 Abundance, Distribution and Movements of Olive Ridley Sea Turtles in Costa Rica, II. Technical Report to the US Fish and Wildlife Service and WWF-US Albuquerque: Fish and Wildlife Service.

Cornelius, S. E., M. A. Alvarado Ulloa, J. C. Castro, M. Malta de Valle, and D. C. Robinson

1991 Management of Olive Ridley Sea Turtles (Lepidochelys olivacea) Nesting at Playas Nancite and Ostional, Costa Rica. In Neotropical Wildlife Use and Conservation, J. G. Robinson and K. H. Redford, eds., pp. 111-135. Chicago: University of Chicago Press.

Deardon, P., and S. Harron

1993 Alternative Tourism and Adaptive Change. Annals of Tourism Research 21:81-102.

Ecotourism Society

1998 Ecotourism Statistical Fact Sheet: General Tourism Statistics. Washington DC: Ecotourism Society.

1992 The Ecotourism Society Document. Washington DC: Ecotourism Society.

Evans-Pritchard, D.

1993 Mobilization of Tourism in Costa Rica. Annals of Tourism Research 20:778-779.

Filion, F. L., J. P. Foley, and A. J. Jacquemot

1994 The Economics of Global Tourism. In Protected Area Economics and Policy: Linking Conservation and Sustainable Development, M. Munasignhe and J. McNeely, eds., pp. 234-254. Washington DC: World Bank.

Gurung, C. P., and M. De Coursey

1994 The Annapurna Conservation Area Project: A Pioneering Example of Sustainable Tourism? In Ecotourism: a Sustainable Option? E. Cater and G. Lowman, eds., pp. 177-194. Chichester: Wiley.

Hughes, D. A., and J. D. Richard

1974 The Nesting of the Pacific Ridley Turtle (Lepidochelys olivacea) on Playa Nancite, Costa Rica. Marine Biology 24:97-107.

Instituto Costarricense de Turismo

1993 Anuario Estadistico de Turismo. San José, Costa Rica: ICT.

Jacobson, S. K., and R. Robles

1992 Ecotourism, Sustainable Development, and Conservation Education: Development of a Tour Guide Training Program in Tortuguero, Costa Rica. Environmental Management 16:701-713.

Johnson, S. A., K. A. Bjorndal, and A. B. Bolten

1996 A Survey of Organized Turtle Watch Participants on Sea Turtle Nesting Beaches in Florida. Chelonian Conservation and Biology 2:60-65.

Johnson, J. D., D. J. Snepenger, and S. Akis 1994 Residents' Perceptions of Tourism Development. Annals of Tourism Research 21:629-642.

Kangas, P., M. Shave, and P. Shave

1995 Economics of an Ecotourism Operation in Belize. Environmental Management 19:669-673. 
King, B., A. Pizam, and A. Milman

1993 Social Impacts of Tourism: Host Perceptions. Annals of Tourism Research 20:650-665.

Kutay, K

1992 Ecotourism Marketing: Capturing the Demand for Special Interest Nature and Culture Tourism to Support Conservation and Sustainable Development. Paper Presented to the Third Inter-American Congress on Tourism, 1992. Cancun, Mexico.

Madrigal, R.

1994 Residents' Perceptions and the Role of Government. Annals of Tourism Research 22:86-102.

March, E.

1992 Diagnóstico sobre Situación Social de la Población de Ostional, Provincia de Guanacaste. Unpublished Report. San José, Costa Rica, University of Costa Rica.

Murphy, P. E.

1985 Tourism: A Community Approach. New York: Methuen.

Naranjo I., and R. Arauz

1994 Local Guides in the Leatherbacks of Guanacaste Marine National Park: Sustained Development and Sea Turtle Conservation. In Proceedings of the 13th Annual Sea Turtle Symposium on Sea Turtle Biology and Conservation, February, 1993, B. A. Schroeder and B. E. Witherington, compilers, pp. 124126. Tallahassee FL: US Department of Commerce.

National Marine Fisheries Service and US Fish and Wildlife Service (NMFS/ USFWS)

1996 Recovery Plan for U.S. Pacific Populations of the Olive Ridley Turtle (Lepidochelys olivacea). Silver Spring MD, National Marine Fisheries Service.

Norris, R.

1992 Can Ecotourism Save Natural Areas? National Parks (January):33-34.

Oppermann, M.

1993 Tourism Space in Developing Countries. Annals of Tourism Research 20:535-556.

Ormans, M. B.

1995 Towards a More Desirable Form of Ecotourism. Tourism Management 16:3-8.

Parry, D., and B. Campbell

1992 Attitudes of Rural Communities to Animal Wildlife and its Utilization in Chobe Enclave and Mababe Depression, Botswana. Environmental Conservation 19(2):45-251.

Schlüter, R. G.

1993 Tourism Development in Latin America. Annals of Tourism Research 20:364-366.

Simmons, D. G.

1994 Community Participation in Tourism Planning. Tourism Management 15:98-108.

Stewart, W. P., and S. Sekartjakrarini

1994 Disentangling Ecotourism. Annals of Tourism Research 21:629-642.

Taylor, G.

1995 The Community Approach: Does it Really Work? Annals of Tourism Research 16:478-489.

Whelan, T.

1991 Ecotourism and its Role in Sustainable Development. In Nature Tourism: Managing for the Environment, T. Whelan, ed., pp. 3-22. Washington DC: Island Press.

Wild, C.

1994 Issues in Ecotourism. In Progress in Tourism, Recreation, and Hospitality Management: Volume 6, C. P. Cooper and A. Lockwood, eds., pp. 12-21. Chichester: Wiley.

World Tourism Organization

1996 Global Overview: Preliminary Results. Madrid: World Tourism Organization. 
Ziffer, K.

1989 Ecotourism. An Uneasy Alliance. Working Paper No. 1. Washington DC: Conservation International.

Submitted 18 July 1997. Resubmitted 15 January 1998. Accepted 2 July 1998. Final version 15 September 1998. Refereed anonymously. Coordinating Editor: Paul F. Wilkinson. 